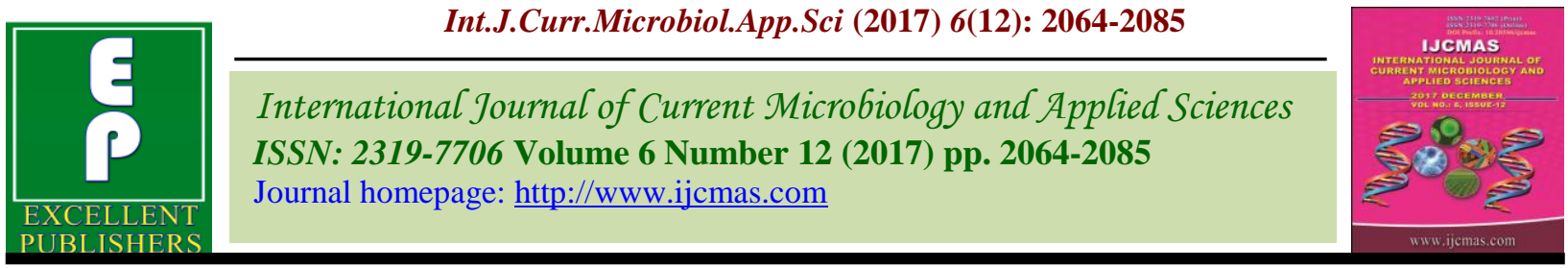

Review Article

https://doi.org/10.20546/ijcmas.2017.612.237

\title{
Review on Rabies and Vaccines
}

\author{
Sunil Abraham ${ }^{1^{*}}$, Jayaishrei Ravindran ${ }^{1}$, Nishawlini Abishaw ${ }^{1}$, \\ Nathaniel Philip Sandam ${ }^{1}$, Prashanth Thimmareddy ${ }^{1}$ and Goutham Govindaraju ${ }^{2}$
}

${ }^{1}$ Geniron Biolabs, R\&D unit, IBAB campus, Electronic city phase I, Bengaluru - 560 100, Karnataka, India

${ }^{2}$ Geniron Biolabs, Lab animal facility \#93, Solur, Anekal Taluk, Bangalore -562 106, Karnataka, India

*Corresponding author

\section{A B S T R A C T}

\begin{tabular}{|l|}
\hline Ke y w or d s \\
Rabies, PEP, \\
RVG, HRIG, ERIG, \\
Vaccine. \\
\hline Article Info \\
\hline $\begin{array}{l}\text { Accepted: } \\
17 \text { October } 2017 \\
\text { Available Online: } \\
10 \text { December } 2017\end{array}$ \\
\hline
\end{tabular}

\section{Introduction}

Rabies is a disease known to mankind since ancient times. It is an acute viral infection caused by the highly neurotropic rabies virus, most often transmitted by the bite of a rabid animal. Once a person or animal begins to record symptoms, almost every case is fatal (Fitzpatrick et al., 2012; Gsell et al., 2012). This makes rabies a feared disease to humans. Human rabies is a major public health concern and is seen as a neglected disease worldwide by the World Health Organization (WHO, 2013a; Vigilato et al., 2013). It is an endemic disease throughout most African and Asian countries (WHO, 2013a). In 95\% of the cases, domestic dogs are the primary reservoir of the virus, which is also chiefly responsible for the transmission of the virus to humans, particularly in India and China.

More than $99 \%$ of all human deaths from rabies occur in the developing countries. The worldwide distribution of rabies has changed since 2010, and most of the rabies deaths occur in Africa, South-East Asia and Western Pacific regions (WHO, 2013a). Rabies has terrified man since olden times. The fear is by no means unfounded since the disease is invariably lethal and perhaps the most 
atrocious and horrible of all communicable diseases in which the sick individual is tortured at the same time with thirst and hydrophobia. The development of rabies can be prevented to a great extent if animal bites are managed appropriately on time. This review provides brief knowledge on rabies, its epidemiology, researches on rabies vaccines and its availability.

\section{Reports on dogs}

\section{Rabies and stray dogs}

Having a large population of stray dogs in a community is considered to be a risk factor for spreading of zoonotic diseases such as rabies (OIE, 2010). Transmission of zoonoses can be controlled by minimizing the population of stray dogs and the number of bite cases (Spiegel, 2000; Beck et al., 2013). Dog ownership includes taking responsibility of the dog's well-being, make certain it does not run around unsupervised and does not present a hazard to people (Hiby, 2013; OIE, 2010). Most of the dog bites are caused by domestic pet dogs rather than dogs in the streets (Spiegel, 2000; Fielding, et al., 2012). If pet dogs wander in the streets, and come in contact with other street dogs, then they are put in risk of becoming infected with rabies. Hence, the dogs if vaccinated against rabies, the risk of rabies infections would be reduced (Fielding et al., 2012). In addition to rabies, stray dogs have serious health hazardous effects on humans of transmitting other diseases like leptospirosis (Chomel and Arzt, 2013) and other parasitic diseases (Morgan, 2013) and they also affect livestock (Rabinowitz et al., 2007). Some of these dangers are perhaps reduced by responsible dog ownership such as deworming of the dog and removal of dog fecal matter from public areas (Morgan, 2013). Most importantly, sterilization is used to prevent unwanted puppies from being born in order to scale down the stray dog population (Hiby, 2013).

\section{Dog bites and its effects}

Dog bites can lead to serious consequences which can be far beyond a wound or abrasion. $76-94 \%$ of animal-bite injuries are caused by dogs (WHO, 2013b). Morbidity is high when the bites leave scars on the victim that lead to disfigurements. It also leads to serious nerve problems which may involve multiple surgeries, therapies, and medication for a long period. Wound, injury, devitalized tissues, damages in the nerve, tendon, bone, and joints also occur (Morgan and Palmer, 2007). The victim will face several psychological disorders such as phobias, anxiety, depression and other stress-related disorders.

An anti-rabies vaccination clinic at a Tertiary Care Hospital Nanded, Maharashtra, India reported 4979 victims in the year 2014-2015 and 4234 victims in the year 2015-2016 (mostly dogs) (Kulkarni, 2016). In 2014 the dog bite rate from the Indian state Tamilnadu was 80/1000 population (Venkatesan et al., 2014). In the year 2014, 63,726 dog bite cases were reported in the state of Telangana (Asma et al., 2016). Institute of Preventive Medicine (IPM), Hyderabad reported that a total number of 872 dog bite victims participated in a crosssectional study conducted in the month of May 2015 (Asma et al., 2016). AntiRabies Vaccination (ARV) outpatient department (OPD) Indira Gandhi Government Medical College, Nagpur, Maharashtra, India, reported 987 animal bite cases (mostly dogs) during the period from May 1, 2015 to October 31, 2015 in a cross-sectional study conducted during this period (Kinge and Supe, 2016). Anti-Rabies Clinic (ARC), Mandya Institute of Medical Sciences (MIMS), Mandya, Karnataka, India conducted 3 years of study (January 2011 to December 2013) which includes a total of 12,798 animal bite victims. This study also includes monkeys and other wild animal victims (Jahnavi et al., 2014). In 
2004 the dog bite rate from Delhi was 25/1000 population (Agarwal and Reddajah, 2004). In 2001 - 2003, it was estimated at 4.5 million bites each year (Gilchrist et al., 2008). In the USA, bat bites are the most common source of rabies infections in human and less than 5\% are from dogs (Tintinalli, 2010).

\section{Dog population control measures}

The main cause for an increase in the number of dog bites is it's high breeding rates. Controlling the stray dogs is one of the challenging criteria. Sterilization is one of the methods for controlling the population of dogs; it is widely implemented by three effective methods such as:

Surgical sterilization: This method includes anesthesia and pain management, which can be handled by a professional veterinarian.

Chemical sterilization or chemical contraception: Chemical sterilants and birth control devices should be employed based on the clinical and research trials.

Separating female dogs from unsterilized male dogs.

Controlling stray dogs has become a large challenge in most Indian cities. Problems of stray dogs persist all over the world, including nations like Saudi Arabia, Cambodia, Pakistan, Iran, Iraq, North Korea, Bhutan, Afghanistan, Jordan, Syria, Yemen, Bangladesh, Nepal, Ukraine and Uzbekistan. The reason behind this is uncontrolled birth and lack of sterilization programs. A report from Humane Society International says that India sterilized and vaccinated 18550 dogs and 74014 dogs, respectively. National Rabies Control Program (NRCP) in the Hisar Division of Haryana, India reported that more than 92000 community dogs received sterilization and/or vaccination and other treatment as part of the first NRCP (HSI, India, 2016).

\section{Nonsurgical method}

Different methods have been tried out in controlling the dog population and vaccination in dogs which is mandatory in many Indian states, and the same is also commonly recommended for cats, deer etc. Hence, as a desirable choice, a combined method of administering sterilant along with rabies vaccine has been investigated in many fields. This should shed a strong public acceptability and would reduce additional visits to the clinic.

For sterility effects, hormones that are effective in controlling reproduction has been studied thoroughly e.g. Gonadotropin releasing hormone $(\mathrm{GnRH})$ and $\mathrm{ZP}$ proteins. Zona pellucida $(\mathrm{Zp})$ is the coating membrane found on the ovum or egg. ZP antigens stimulate antibodies that stick to the airfoil of the eggs, which can prevent sperm from binding and therefore it blocks the fertilization (Purswell and Kolster, 2006). Gonadotrophin releasing hormone (GnRH) stimulates and synthesizes two gonadotropins such as luteinizing hormone ( $\mathrm{LH}$ ) and follicle stimulating hormone (FSH), secreted from the anterior pituitary gland affecting the secretion of estrogen and testosterone. This holds an advantage of suppressing sexual behaviors in male and female stray dogs (Kutzler and Wood, 2006). The effects of GnRH peptide as an immunocontraceptive have been studied effective in different animal species in both genders (Van der Zee et al., 1995; Levi et al., 2004; Conforti et al., 2007; Munson, 2006). Neither serious side-effects nor harmful social behavior changes have been observed in the GnRH-immunized animals.

On the other hand, cytotoxin conjugates are one of the most promising sterilization 
vaccines, which are plant-derived toxins linked to GnRH. These conjugates when injected into the body it binds to the gonadotrophin cells, thus they destroy these cells and inhibit the release of $\mathrm{LH}$ and FSH (WSPA, 2007). List of available animal rabies vaccines in India is presented in Table 1. GonaCon $^{\mathrm{TM}}$ (National Wildlife Research Centre, USDA), Canine Gonadotrophin Immunotherapeutic Factor (Pfizer Animal Health, Exton, PA, USA), SpayVac ${ }^{\mathrm{TM}}$ (Spay Vac for Wildlife Inc.) are the immunocontraceptives currently used to control dog population.

\section{Epidemiology of rabies}

\section{Geographical distribution of rabies}

Rabies is present in 150 countries and all continents except Antarctica. Stray dogs are a principal source of infections in humans in many parts of Asia and Africa (ECDC, 2016). Most of the events of human rabies occur in poor regions of Africa and Asia; canine rabies is endemic and appropriate facilities are often not available for intensive medical care (Jackson, 2013). A colored geographical map representing rabies affected areas worldwide is shown in Figure 1. A number of rural areas including Australia, Canada, Japan and the United States and Western Europe and Island nations do not have rabies among dogs (CDC, 2014). As per CDC reports, some of the countries like Australia, New Zealand, the United Kingdom, Japan, Singapore, Papua New Guinea and the Pacific islands are free of dog rabies (CDC, 2017) though circulating viruses are prevalent, these countries are listed as rabies-free when importation of dogs to the USA is considered.

\section{Human deaths by rabies}

Canine rabies causes approximately 59000 human deaths globally (37266 deaths in Asia;
21509 in Africa and 182 in Latin America) (Hampson et al., 2015) and 50\% of the death cases are reported in Asian and African regions (CDC, 2016). In Asia, India has the highest number of human death caused by rabies (WHO, 2016). A report claims that an average of 18000 - 20000 death cases come in India due to rabies (Kole, 2014; Dutta, 1999). Over 30000 deaths every year due to rabies in Asia (WHO, 2016). Four out of every ten deaths from rabies are in children aged less than 15 years (WHO, 2016). Out of 36 rabies patients, just five survived rabies infection after showing symptoms, and the patients had undergone extensive treatment known as the Milwaukee protocol (Hemachudha et al., 2013). The Island of Bali in Indonesia has been undergoing a serious eruption of canine rabies since 2008 and has also killed about 78 people as of late September 2010 (Hampson et al., 2015). About 583.5 million USD is spent annually for rabies prevention (Knobel et al., 2005). Rabies causes about 24000 to 60000 deaths worldwide per year (Giesen et al., 2015) and also causes 8.6 billion USD economic losses annually (Hampson et al., 2015).

\section{Rabies virus and its genome structure}

Rabies virus belongs to the order Mononegavirales i.e. viruses with nonsegmented and negative-stranded RNA genomes. They belong to the genus - Lyssa virus in the Rhabdoviridae family that targets the central nervous system. They are bullet shaped and measures about approximately $180 \mathrm{~nm}$ long and $75 \mathrm{~nm}$ wide (Figure 2A). The genome encodes five proteins classified as Nucleoprotein (N), Phosphoprotein (P), Matrix protein (M), Glycoprotein (G) and Large protein (L). The ordination and placement of these proteins encoding genes in the genome influence the structure of the virus (Figure 2B). 
Formation of rhabdoviruses requires an intricate interplay of RNA transcription and replication of the nucleoprotein $\mathrm{N}$ (450 aa), RNA-dependent RNA polymerase (RdRp) L (2130 aa), non-enzymatic polymerase cofactor P (297 aa), and the RNA genome enwrapped by $\mathrm{N}$ protein (also called the nucleocapsid). Phosphoprotein binds the Large protein to the Nucleoprotein-RNA template through an interaction of Nucleoprotein-Phosphoprotein complex that involves two adjacent Nucleoproteins in the nucleocapsid during RNA synthesis. Large protein-Phosphoprotein binding to the Nucleoprotein-RNA complex triggers conformational changes which allow the access of polymers to the RNA. Ribonucleoprotein (RNP), the component active in transcription and replication is formed by the RNA, Nucleoprotein, Phosphoprotein, and Large protein complex. The matrix protein M (202 aa) and glycoprotein G (505 aa) are membraneassociated proteins where the later is an integral transmembrane protein involved in viral entry (Albertini et al., 2011) and is responsible for the pathogenesis, discussed in section 6 of this review.

\section{Pathogenesis of rabies virus}

When a rabid animal bite, the saliva from the bite containing infectious rabies viruses which are important for transmission to other hosts will be inoculated into subcutaneous tissues and muscles. The rabies virus binds to nicotinic acetylcholine receptors at the neuromuscular junction (Lentz et al., 1982). The virus travels towards the central nervous system (CNS) at a rate of $12-100 \mathrm{~mm} /$ day (Kucera et al., 1985; Lycke and Tsiang, 1987; Tsiang et al., 1991). The virus multiplies in the CNS, where it causes encephalitis (inflammation of the brain) (Figure 3) involving the parasympathetic nervous system, which is responsible for the infection
(Jackson, 2007; Kucera et al., 1985). The virus runs out through the peripheral nerves and invests in most other organs, especially salivary glands, skin, mucosal surfaces, and gut. Death occurs if the salivary infection lasts up to 2 weeks before the appearance of signs. Studies performed on skunks, using reverse transcriptase-polymerase chain reaction (RT-PCR) showed viral genomic RNA was present in the inoculated muscle but absent in spinal cord or spinal ganglia (Jackson, 2010).

\section{Rabies virus glycoprotein (rvg) importance in protecting animals}

The glycoprotein gene is a membraneassociated molecule and a major component on the surface of mature rabies virions (spikelike projections); considered to be responsible for the induction of neutralizing antibodies to the virus (Dietzschold et al., 1978; Wiktor et al., 1973; Cox et al., 1977). The trimeric G protein (Figure 2C) is the only rabies viral protein exposed on the surface of the virion, responsible for the adhesion to the target cell by interaction with several cell membrane components, thus the virus gets into the cell by endocytosis (Toulouze, et al., 1998).

Fusion between virus and the cell membrane is triggered when the acidic $\mathrm{pH}$ in the endosome induces conformational changes in the glycoprotein trimer. In vitro evidence showed that the nicotinic acetylcholine receptor (nAChR), the neuronal cell adhesion molecule (NCAM), and the p75 neurotrophin receptor (p75NTR) bind glycoprotein and facilitate rabies virus entry into cells. RVG is a specific high affinity ligand for a nonneurotrophin binding site on the $\mathrm{p} 75$ receptor (Christelle et al., 2002).

During infection and vaccination, the glycoprotein plays a major role as an antigenic stimulant and induces neutralizing 
antibodies (Jemima et al., 2014). Several studies have confirmed that glycoprotein gives protection against rabies. This gene can also reduce viral pathogenicity and enhance immunogenicity (Faber et al., 2002). Arginine (AGA) mutated into Glutamic acid (GAG) at the amino acid position 333 in the recombinant RVG has displayed more immunogenicity (Dietzschold et al., 1983; Tuffereau et al., 1989).

\section{History of rabies vaccine}

Louis Pasteur, a French scientist, acquired a vaccine in the year 1885 to prevent rabies. The vaccine saved many human and animal lives. French called him Monsieur Pasteur! Monsieur meaning "thank you". The first vaccine was produced by air-drying of the infected rabbit spinal cord in potassium hydroxide and he called it as a live attenuated vaccine. Joseph Meister, a 9 year old boy on $5^{\text {th }}$ July 1885 who was bitten by a rabid dog and was injected with this vaccine. He was injected 13 doses and the similar way the second patient also received the same dose, by the mid of 1886 he treated more than 700 patients and the majority of all survived. In the year 1887, rabies vaccine developed by Pasteur was recognized by the Medical Community for therapeutic purpose.

The rabies vaccine produced during Pasteur's period was applied worldwide for $\sim 10$ years until 1895. Later, carbolic acid-inactivated nervous tissue-derived vaccines were introduced, followed by phenol-inactivated nervous tissue-derived vaccines in the year 1915 (McGettigan, 2010). Until the mid$1950 \mathrm{~s}$, these vaccines were in practice for about 40 years followed by the production of tissue culture-derived, inactivated rabies virus vaccine which is still in use today. A typical flowchart of rabies vaccines from Pasteur to present is presented in Figure 4.

\section{Rabies vaccine}

There are three primary types of rabies viral vaccines - neurotissue vaccines, cell culture vaccines, and embryonated egg vaccines (Figure 5).

The presently available vaccines are reported below:

\section{Neurotissue vaccine}

(Neural vaccines) is produced by growing the virus in the spinal cord of rabbits and then inactivated with beta-propiolactone (BPL). Nerve tissue vaccines are less immunogenic and also cause serious adverse reactions, including a possible risk of rabies from incomplete virus inactivation (Plotkin, 2008). They are however used in a few developing countries (WHO, 2012). Adverse reactions are caused due to hypersensitivity reaction to the myelin thus it has been replaced by a human diploid cell culture-derived vaccine (also inactivated) which is safe and easily tolerated (Briggs et al., 2000; Ajjan et al., 1989) (Discovery of Neural Tissue Vaccine are shown in Table 2). Neurotissue vaccines have been supplanted by cell culture vaccines and embryonated egg vaccines in industrialized nations.

\section{Semple rabies vaccine}

It is prepared by rabies virus infected goat or sheep brain tissue. The Semple antirabies vaccine was produced by David Semple in India in 1911. Semple prepared this vaccine by using the carbolized dead virus. It needs administration around the stomach over a period of 7 to 14 days, a course that many do not finish. WHO abandoned its use in 1993 (Chakrabarti, 2010). 
Table.1 List of available dog and animal rabies vaccines in India 2016

\begin{tabular}{|l|l|l|l|l|}
\hline \multicolumn{1}{|c|}{ Type } & Brand Name & \multicolumn{1}{c|}{ Produced By } & \multicolumn{1}{c|}{ Animals immunized } \\
\hline Inactivated cell culture Vaccine & Rabisure & Indian Immunologicals Ltd., India. & Dogs and cats \\
\hline $\begin{array}{l}\text { Inactivated tissue culture Vaccine } \\
\text { (BHK21 cell line) }\end{array}$ & Raksharab & Indian Immunologicals Ltd., India. & Dogs and other domestic animals & SC/IM \\
\hline Inactivated cell culture vaccine & Starvac-R & Indian Immunologicals Ltd., India. & Dogs and other domestic animals & SC/IM \\
\hline Killed vaccine & Nobivac 3 & $\begin{array}{l}\text { Zoetis Inc., Kalamazoo, MI 49007, } \\
\text { USA. }\end{array}$ & Dogs, cats and sheep & SC/IM \\
\hline Killed virus vaccine & Rabvac 1 & $\begin{array}{l}\text { BoehringerIngelheim Vetmedica, } \\
\text { Inc. St. Joseph, MO 64506 U.S.A. }\end{array}$ & Dogs and cats \\
\hline Killed virus vaccine & Rabvac 3 & $\begin{array}{l}\text { BoehringerIngelheim Vetmedica, } \\
\text { Inc. St. Joseph, MO 64506 U.S.A. }\end{array}$ & Dogs, cats, and horses. \\
\hline Inactivated VERO cell culture vaccine & Rabies vet & Biomed Pvt. Ltd., India & Dogs, cattle, sheep \& goat \\
\hline Inactivated cell culture Vaccine & Rabies vaccine & $\begin{array}{l}\text { Pasteur Institute of India, Coonor, } \\
\text { India. }\end{array}$ & Dogs & SC/IM \\
\hline $\begin{array}{l}\text { Inactivated cell culture Vaccine } \\
\text { (BHK21 cell line) }\end{array}$ & DELCAVAC-r & $\begin{array}{l}\text { Brocades (G.B.) Ltd., Braintree, } \\
\text { Essex, U.K. }\end{array}$ & Dogs and cats \\
\hline Inactivated vaccine & RABISIN & $\begin{array}{l}\text { Merial, Sanofi-aventis Philippines, } \\
\text { Inc. }\end{array}$ & Dogs, cats and cattle. \\
\hline
\end{tabular}

IM-Intramuscular, SC-Subcutaneous.

Table.2 Discovery of Neural Tissue Vaccines (NTV)

\begin{tabular}{|l|l|l|l|l|}
\hline S.No & \multicolumn{1}{|c|}{ Vaccine } & \multicolumn{1}{c|}{ Type } & \multicolumn{1}{c|}{ Year } & \multicolumn{1}{c|}{ Discovered by } \\
\hline 1 & Hogyes Vaccine & Live attenuated & 1887 & Endre Hogyes \\
\hline 2 & Puscariu Vaccine & Inactivated & 1895 & E.Puscariu \\
\hline 3 & Babes Vaccine & Inactivated & 1912 & Victor Babeș \\
\hline 4 & Semple Vaccine & Inactivated & 1911 & David Semple \\
\hline 5 & Hempt Vaccine & Inactivated & $1925 \& 1938$ & Adolf Hempt \\
\hline 6 & Suckling Mouse Brain Vaccine & Inactivated & 1955 & Fuenzalida and Palacios \\
\hline 7 & Suckling rat Brain Vaccine & Inactivated & 1955 & Svet-Moldavskij et al., \\
\hline 8 & Suckling Rabbit Brain Vaccine & Inactivated & 1955 & - \\
\hline
\end{tabular}


Table.3 Summary of Rabies vaccines with mild and adverse reactions

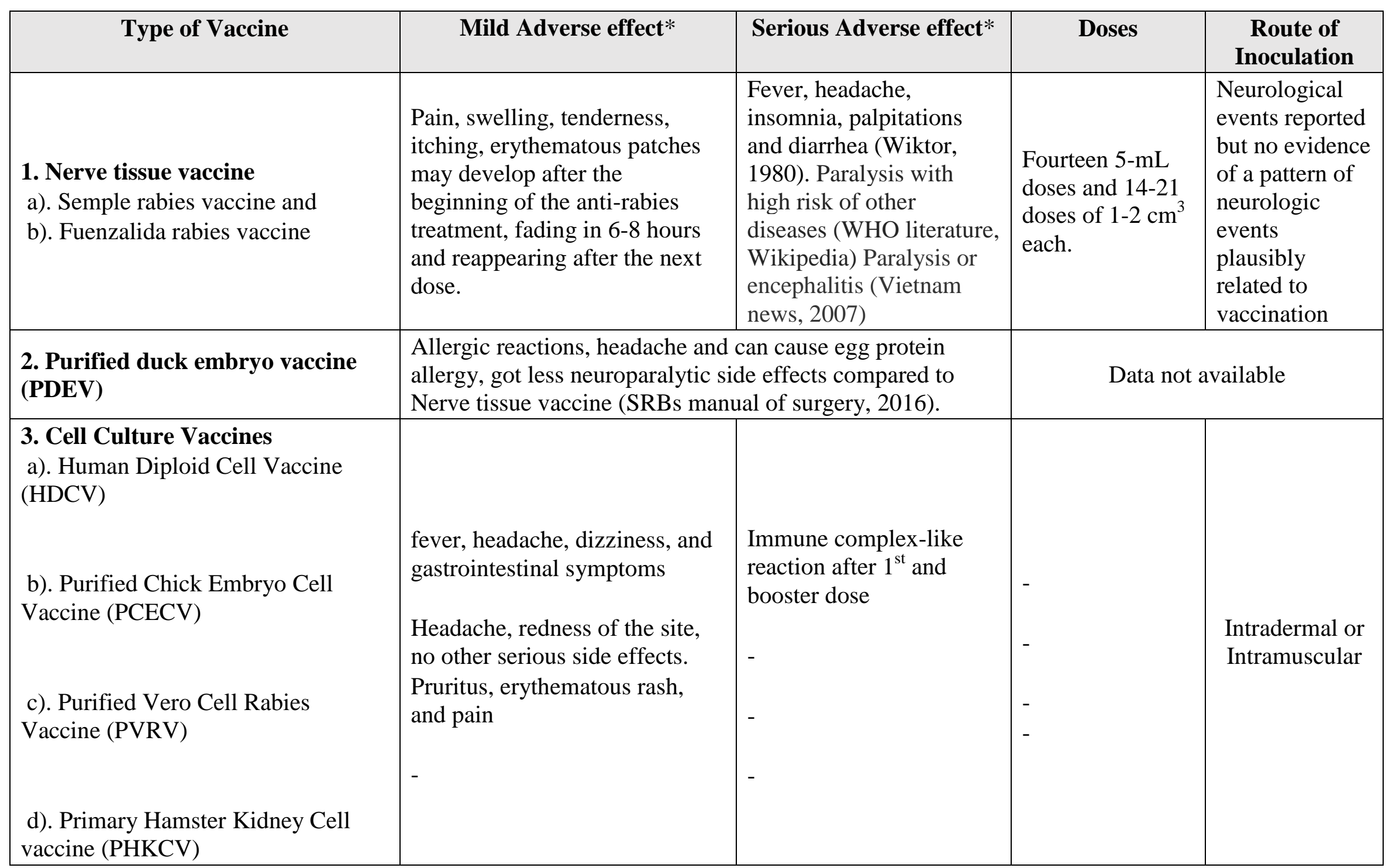

* Mild and serious adverse effects may not be same for all people; it may vary from person to person. 
Table.4 Human rabies vaccine manufactured and marketed in India 2016

\begin{tabular}{|c|c|c|c|c|}
\hline Type & Brand Name & Produced by & Route & Price/volume* \\
\hline Purified Vero Cell Rabies Vaccine (PVRV) & Abhayrab & Human Biologicals, India & $\mathrm{IM} / \mathrm{SC}$ & $315.00 / 1$ \\
\hline Human Diploid Cell Vaccine (HDCV) & Imovax & Sanofi Pasteur, France & IM & - \\
\hline Human Diploid Cell Vaccine (HDCV) & Rabies Vaccine, HDC & Serum Institute, India & IM & $1125.66 / 1 \mathrm{ml}$ \\
\hline $\begin{array}{l}\text { Purified Chick Embryo Cell Vaccine } \\
\text { (PCECV) }\end{array}$ & Rabipur & $\begin{array}{l}\text { Novartis Vaccines and } \\
\text { Diagnostics GmbH, Germany }\end{array}$ & $\mathrm{IM}$ & $371.60 / 1 \mathrm{ml}$ \\
\hline Human Diploid Cell Vaccine (HDCV) & SII Rabivax HDCV & Serum Institute, India & $\mathrm{IM}$ & $\begin{array}{l}\text { Vial- 355.00/1 } \\
\text { Amp- 454.30/1 }\end{array}$ \\
\hline $\begin{array}{l}\text { Purified Chick Embryo Cell Vaccine } \\
\text { (PCECV) }\end{array}$ & Vaxirab-N & Zydus (Biogen), India & $\mathrm{IM} / \mathrm{ID}$ & $294.00 / 1 \mathrm{ml}$ \\
\hline Purified Vero Cell Rabies Vaccine (PVRV) & Verorab & Sanofi Pasteur, France & IM & $369.00 / 1 \mathrm{ml}$ \\
\hline Purified Vero Cell Rabies Vaccine (PVRV) & Verovax-R & Aventis Pasteur, India. & IM & $296.00 / 0.5 \mathrm{ml}$ \\
\hline Purified Vero Cell Rabies Vaccine (PVRV) & Worab Vaccine, & Wockhardt (MCC), India & - & $310.00 / 0.5 \mathrm{ml}$ \\
\hline Purified Vero Cell Rabies Vaccine (PVRV) & Vacrabies & Synergy diagnostics, India & - & $325.00 / 1$ \\
\hline Purified Vero Cell Rabies Vaccine (PVRV) & Zoonovac- V & Bharat Serum, India & $\mathrm{IM} / \mathrm{ID}$ & $337.48 / 1$ vial \\
\hline Purified duck embryo vaccine (PDEV) & Lyssavac-N & $\begin{array}{l}\text { Cadila, Berna Biotech, } \\
\text { Switzerland. }\end{array}$ & $\mathrm{IM}$ & Rs.816.00/1ml \\
\hline $\begin{array}{l}\text { Chromatographically, Purified Vero Cell } \\
\text { Rabies Vaccine (PVRV) }\end{array}$ & INDIRAB & Bharat Biotech, India & $\mathrm{IM} / \mathrm{ID}$ & $710.00 / 5 \mathrm{ml}$ \\
\hline Human Diploid Cell Vaccine (HDCV) & $\begin{array}{l}\text { Rabies Vaccine } \\
\text { (Human) }\end{array}$ & Haffkine, India & - & $168.20 / 30 \mathrm{ml}$ \\
\hline Vero cell derived DNA rabies vaccine & Antirabies vaccine & $\begin{array}{l}\text { Pasteur Institute, Conoor. } \\
\text { India. }\end{array}$ & - & - \\
\hline
\end{tabular}

IM-Intramuscular, ID-Intradermal, SC-Subcutaneous.

*All the price details are from the producers/marketers; price may also vary according to the marketers. 
Table.5 Equine Rabies Immunoglobulin (ERIG) manufactured and marketed in India 2016

\begin{tabular}{|c|c|c|c|c|c|}
\hline Vaccine & Brand name & Route & $\begin{array}{l}\text { Dosage \& } \\
\text { Admn. }\end{array}$ & Adverse effects $\dagger$ & Pharmaceuticals \\
\hline \multirow{9}{*}{ 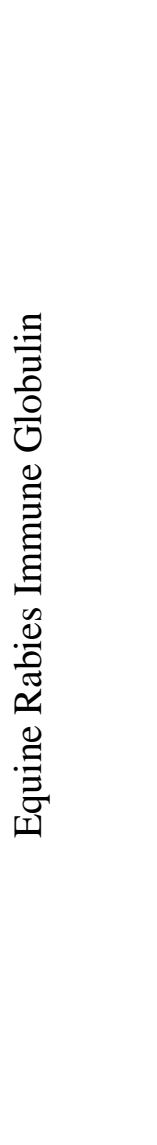 } & CARIG & \multirow{9}{*}{ 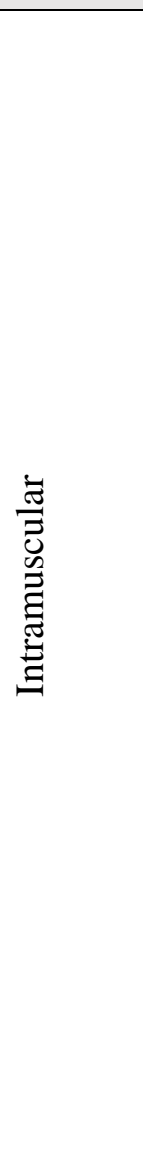 } & \multirow{9}{*}{ 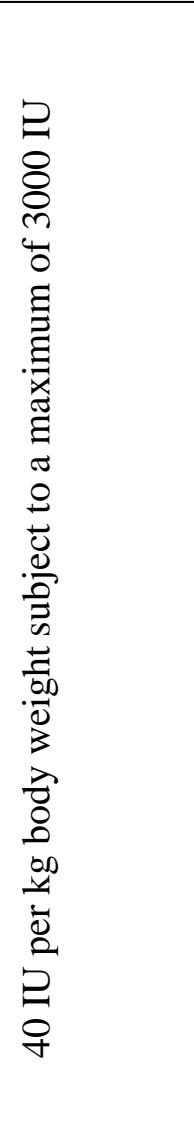 } & $\begin{array}{l}\text { Erythema \& Serum sickness like reactions may occur in about } 1 \text { to } \\
2 \% \text { subjects after six days of RIG administration }\end{array}$ & $\begin{array}{l}\text { Cadila Pharmaceuticals, } \\
\text { Ahmedabad }\end{array}$ \\
\hline & EQUIRAB & & & $\begin{array}{l}\text { Fever, pruritis, rash, urticaria, erythema, lymph adenopathy and } \\
\text { arthralgia }\end{array}$ & $\begin{array}{l}\text { Bharath Serums and } \\
\text { Vaccines Ltd, Mumbai }\end{array}$ \\
\hline & $\begin{array}{l}\text { PASTEUR } \\
\text { ANTIRABIES } \\
\text { SERUM } \\
\end{array}$ & & & $\begin{array}{l}\text { Headache, dizziness, malaise, abdominal pain, nausea, myalgia. } \\
\text { Inj-site reactions such as itching, swelling, pain. }\end{array}$ & $\begin{array}{l}\text { Cadila Healthcare, } \\
\text { (Zydus Cadila } \\
\text { Healthcare Ltd.) }\end{array}$ \\
\hline & IMORAB & & & $\begin{array}{l}\text { Soreness at the injection site, Fever, Skin rash, Nephrotic } \\
\text { syndrome. }\end{array}$ & Aventis Pasteur, France \\
\hline & PARS & & & $\begin{array}{l}\text { High fever, Weakness, Trouble speaking, Swallowing, Pain, } \\
\text { Swelling, Itching, Headache, Dizziness, Muscle pain, Nausea, } \\
\text { Stomach pain. (data sheet) }\end{array}$ & $\begin{array}{l}\text { Newgen (Cadila } \\
\text { Pharmaceuticals, Ltd.) }\end{array}$ \\
\hline & $\begin{array}{l}\text { ANTI RABIES } \\
\text { SERUM }\end{array}$ & & & $\begin{array}{l}\text { Pain, swelling, itching, or redness where the shot was given, } \\
\text { headache, dizziness, muscle pain or nausea, stomach pain. }\end{array}$ & $\begin{array}{l}\text { Manufactured by VINS, } \\
\text { Hyderabad. }\end{array}$ \\
\hline & ABHAYRIG & & & Nausea, Skin rash, Stomach upset, Acute toxicity & $\begin{array}{l}\text { Manufactured by VINS, } \\
\text { Hyderabad \& Marketed } \\
\text { by Human Biologicals } \\
\text { Institute, Hyderabad }\end{array}$ \\
\hline & VINRIG & & & Nausea, Skin rash, Stomach upset, Acute toxicity & $\begin{array}{l}\text { Manufactured by VINS, } \\
\text { Hyderabad \& Marketed } \\
\text { by Ace } \\
\text { Pharmaceuticals, }\end{array}$ \\
\hline & FAVIRAB & & & $\begin{array}{l}\text { Serum sickness like reactions, fever, pruritus, Erythema, } \\
\text { adenopathy and arthralgia may occur. (data sheet) }\end{array}$ & $\begin{array}{l}\text { Sanofi Pasteur, SA } \\
\text { 2, avenue Pont Pasteur }\end{array}$ \\
\hline
\end{tabular}

Note:

The currently available Equine Rabies Immunoglobulins (ERIGs) are purified, safe, economical and effective,

Majority of reactions to ERIG result from complement activation and are not IgE mediated and will not be predicted by skin testing.

Not every side effect occurs in every person. Medicines that are approved for sale by governments are expected to be safe for the general population, although new or un-reported side effects may be found later. It is must to consult the doctor if any of these side effects occur even in mild form.

$\dagger$ Adverse effects shown are taken from www.tabletwise.com 
Table.6 Human Rabies Immunoglobulin (HRIG) manufactured and marketed in India 2016

\begin{tabular}{|c|c|c|c|c|c|}
\hline Vaccine & Brand name & Route & $\begin{array}{c}\text { Dosage \& } \\
\text { Admn. }\end{array}$ & Adverse effects & Pharmaceuticals \\
\hline \multirow{6}{*}{ 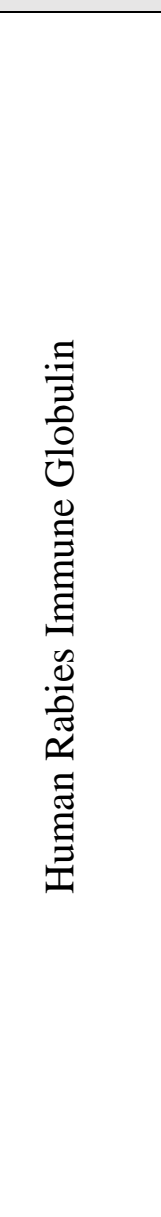 } & $\begin{array}{l}\text { Imogam }{ }^{\circledR} \text { Rabies- } \\
\text { HT }\end{array}$ & \multirow{6}{*}{ 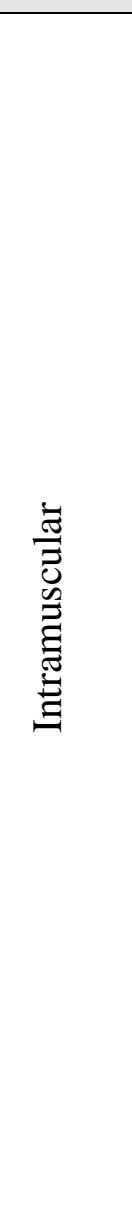 } & \multirow{6}{*}{ 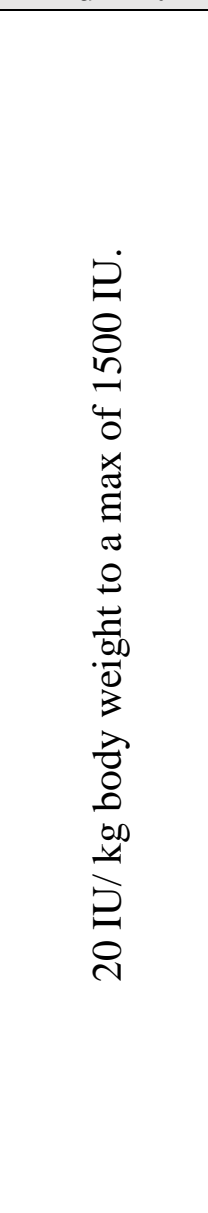 } & $\begin{array}{l}\text { Headache and malaise and other local effects may occur at the } \\
\text { injection site (Jaiiaroensup, 1998) }\end{array}$ & $\begin{array}{l}\text { Mfd. by Aventis } \\
\text { Pasteur, France and } \\
\text { Marketed by } \\
\text { Ranbaxy, Gurgaon, } \\
\text { Haryana. }\end{array}$ \\
\hline & HyperRab TM S/D & & & $\begin{array}{l}\text { Soreness, Angioneuretic, edema, skin rash, nephritic syndrome } \\
\text { and anaphylactic shock (HyperRAB, 2008) }\end{array}$ & $\begin{array}{l}\text { Grifols Therapeutics, } \\
\text { Research Triangle } \\
\text { park, NC, USA. }\end{array}$ \\
\hline & BERIRAB-P & & & $\begin{array}{l}\text { Individuals who are deficient in } \operatorname{Ig} \mathrm{A} \text { have the potential for } \\
\text { developing IgA antibodies and may have anaphylactic } \\
\text { reactions after administration of blood components containing } \\
\text { IgA, moderate back pain (data sheet) }\end{array}$ & $\begin{array}{l}\text { Mfd. by Aventis } \\
\text { Behring, Germany } \\
\text { and Marketed by } \\
\text { Cadila Health Care, } \\
\text { Ahmedabad }\end{array}$ \\
\hline & RABGLOB & & & $\begin{array}{l}\text { Mild, local reactions to the rabies vaccine, such as pain, } \\
\text { redness, swelling, or itching at the injection site (data sheet) }\end{array}$ & $\begin{array}{l}\text { Bharath Serums and } \\
\text { Vaccines Ltd. } \\
\text { Mumbai }\end{array}$ \\
\hline & BayRab & & & $\begin{array}{l}\text { Mental activity changes, Metabolic changes, Growth rate } \\
\text { alteration (Data sheet) }\end{array}$ & $\begin{array}{l}\text { Bayer Corporation } \\
\text { Pharma. Division } \\
\text { Elkhart, IN } 46515 \\
\text { USA }\end{array}$ \\
\hline & Kamrab & & & $\begin{array}{l}\text { Results showed that Kamada's IgG was safe and well tolerated } \\
\text { with no drug-related Serious Adverse Events (SAEs) } \\
\text { experienced (Kamada's Media News Dec. 23, 2015) }\end{array}$ & $\begin{array}{l}\text { Mfd. by Kamada, } \\
\text { Israel and Marketed } \\
\text { by Synergy } \\
\text { Diagnostics, Ltd. } \\
\text { Thane, Maharashtra }\end{array}$ \\
\hline
\end{tabular}

Note:

These are imported and expensive. These are available as $2 \mathrm{ml}$ vials with a potency of $150 \mathrm{IU} / \mathrm{ml}$. HRIGs are to be used when they are can be afforded by the patients.

Not every side effect occurs in every person. Medicines that are approved for sale by governments are expected to be safe for the general population, although new or un-reported side effects may be found later. It is must to consult the doctor if any of these side effects occur even in mild form. 
Fig.1 Representation of worldwide distribution of rabies virus affected area continent wise. Red indicates highly affected, pale yellow indicates mildly affected and white showing countries with rabies free of dogs.

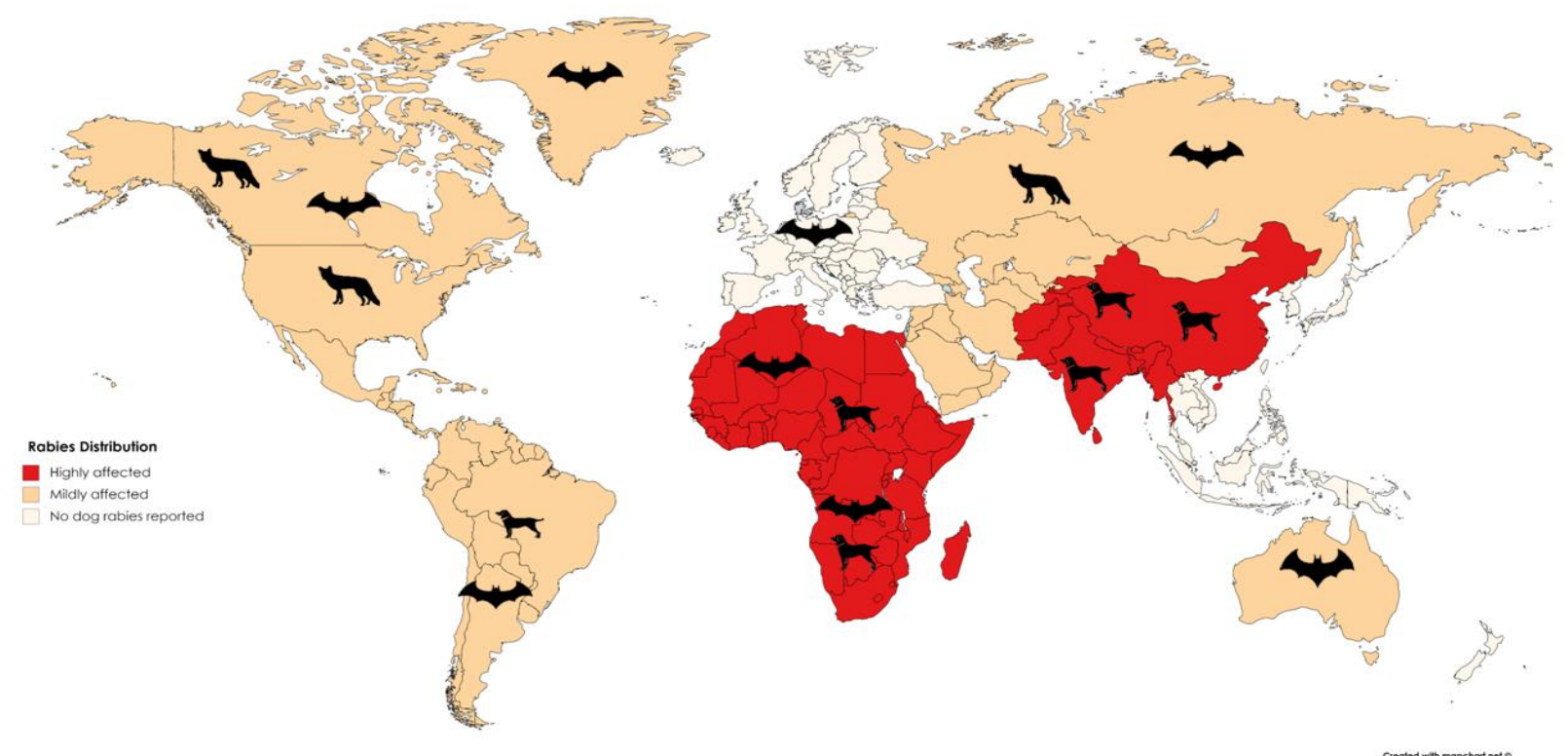

Fig.2 A) Diagrammatic representation showing bullet shaped structure of rabies virus. B)

Different protein structures encoding the genome of rabies virus with the lengths of it; Glycoprotein $(\mathrm{G})$ is shown with its signal, ectodomain, transmembrane and $\mathrm{C}$ terminal $(\mathrm{CT}) \mathrm{C}$ ) Three dimensional structure of Rabies Virus Glycoprotein (RVG)

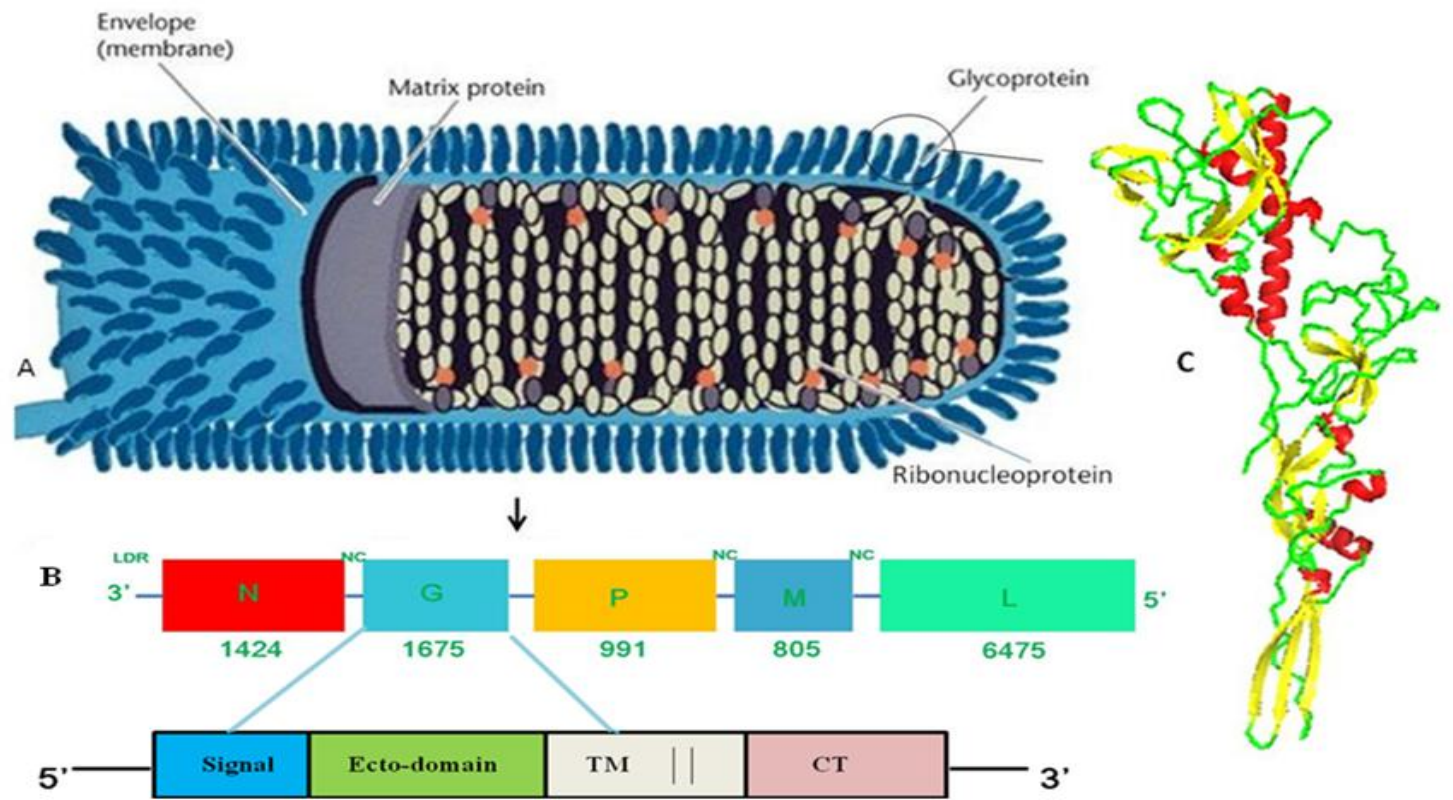


Fig.3 Typical representation of the pathogenesis of rabies virus, where the virus infects the brain and leads to encephalitis, the virus also moves out and infects most other organs especially salivary glands, skin, mucosal surfaces and gut

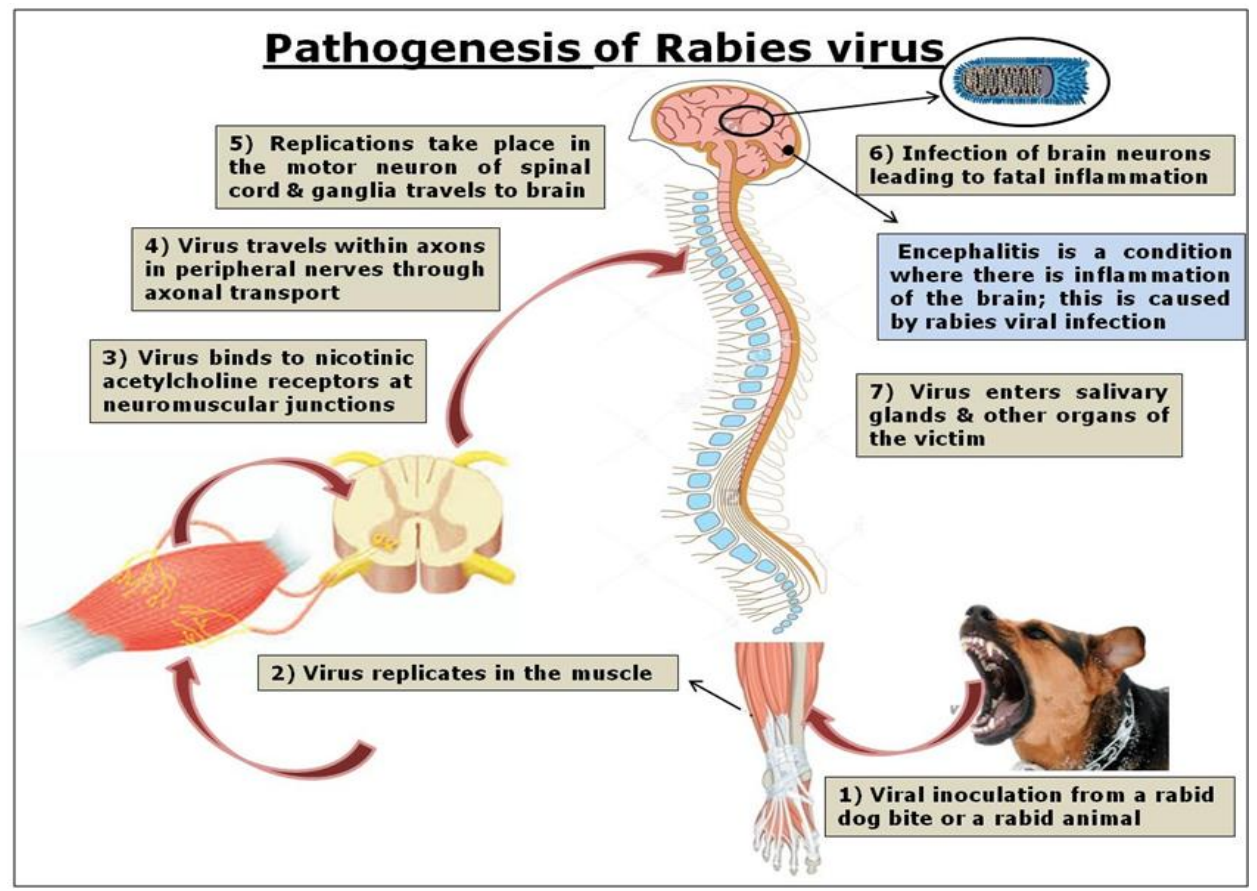

Fig.4 Diagrammatic classification showing the discoveries of rabies vaccines from Pasteur to present

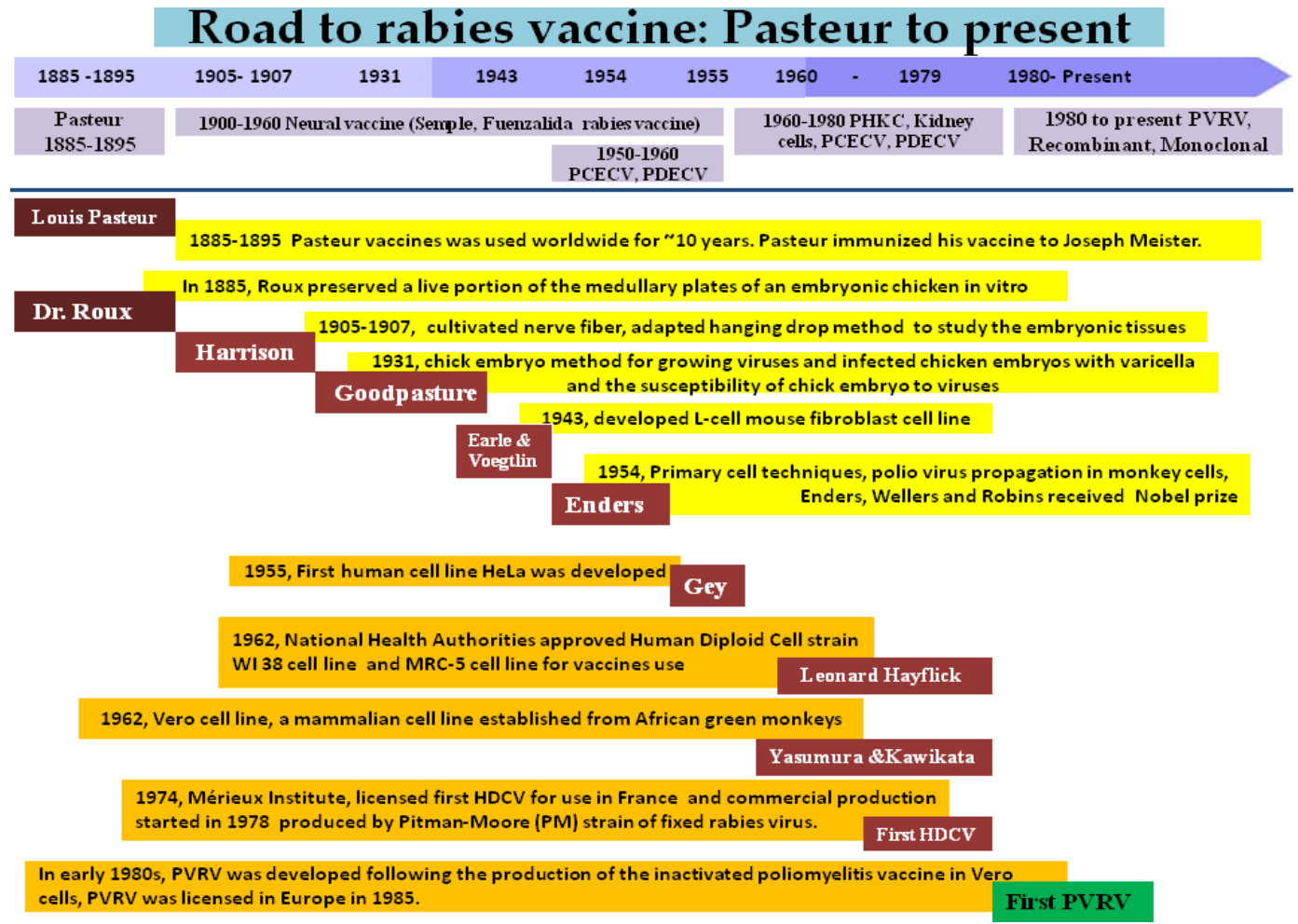


Fig.5 Classification of antirabies vaccines: neural and non-neural vaccines. PVRV, the cell culture based vaccines comes under the class of non- neural vaccines which is in current use

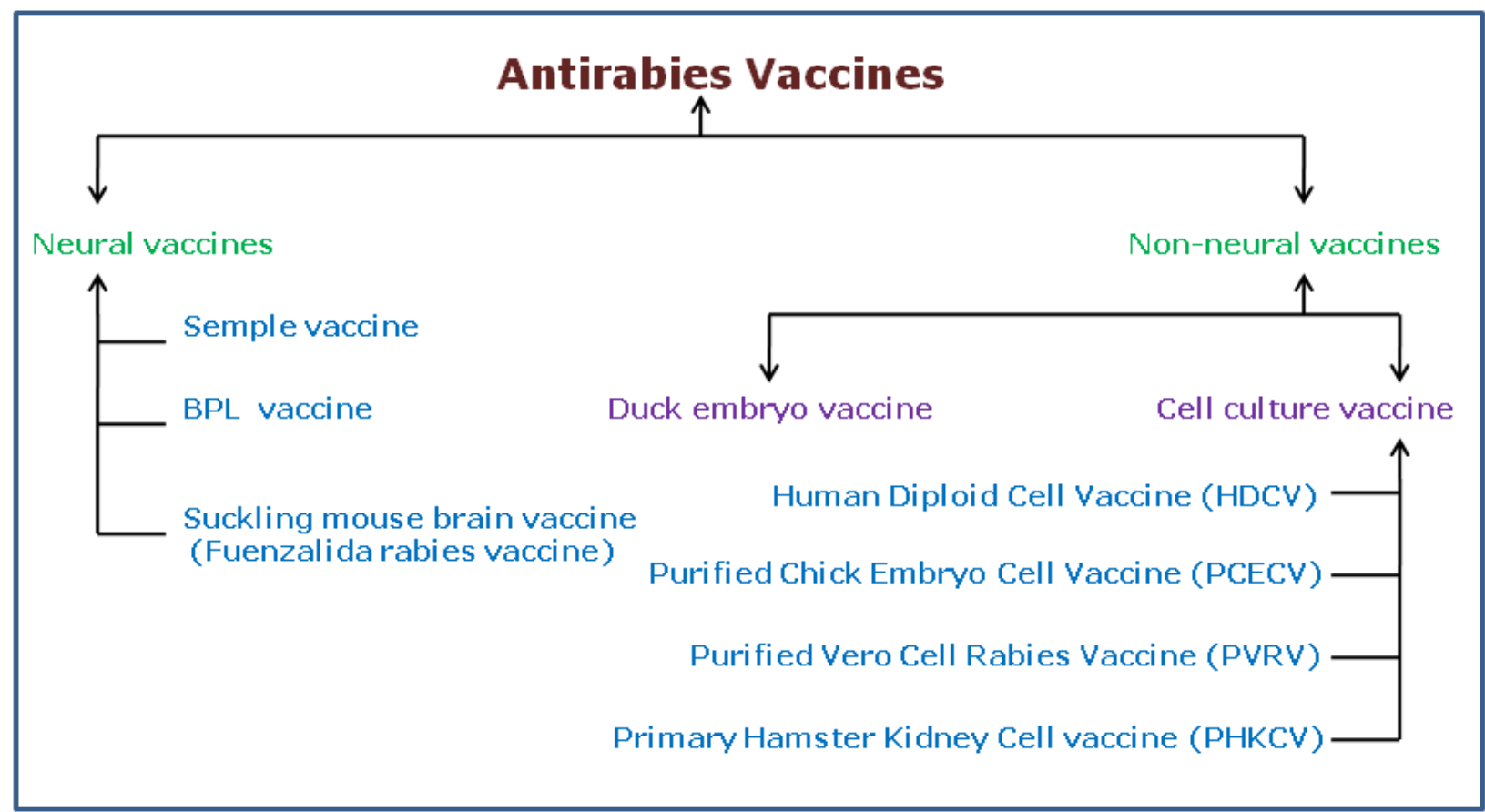

This vaccine is used only in few Asian and African countries since modern vaccines are available all over the world (WHO, 2012).

\section{Fuenzalida rabies vaccine}

It is prepared from suckling mouse brain tissue and has decreased myelin content (Nogueira, 1998). This vaccine is applied in a modest number of Latin American nations.

\section{Embryonated egg-based vaccines (EEV) (Non-neural vaccines)}

\section{Purified duck embryo vaccine (PDEV)}

It is prepared from duck embryo cells. PDEV contains thiomersal (WHO, 2012). This was the first vaccine produced for human use rabies. It was produced in 1957 as a $\beta$ propiolactone inactivated and purified by ultracentrifugation. This is given as an intradermal injection over several days. WHO still includes DEV in its list of recommended vaccines for the treatment of rabies virus exposure.

\section{Cell Culture Vaccines (Non-neural vaccines)}

First generation vaccine

\section{Human Diploid Cell Vaccine (HDCV)}

Introduced in 1978 as a first generation vaccine which contains strains like Flury or Pitman-Moore L503 of rabies virus. This is a $\beta$-propiolactone inactivated intramuscular vaccine for use in human (Wiktor et al., 1980; Keller et al., 1984). A study was conducted with eight healthy human adults who received $20 \mathrm{IU} / \mathrm{kg}$ intramuscular dose of HRIG followed by the treatment with solvent/detergent, HyperRAB S/D; serum was analyzed for the passive rabies antibody titers within 24 hours post-injection and the study period endured for 21 days. These results showed similarity with the earlier results of 
non-solvent/detergent treated product (Plotkin, 1977; Hafkin et al., 1978). The clinical evaluation report was submitted to Europe and US for the use of HDCV.

\section{Second generation vaccine}

\section{Purified Chick Embryo Cell Vaccine (PCECV)}

PCECV is produced in primary cultures of chick fibroblasts by growing Flury LEP-25 (Gluck et al., 1984). This $\beta$-propiolactone inactivated virus is purified and concentrated by zonal centrifugation (CDC, 1998; Dreesen, 1997). This vaccine was first marketed in 1984 and is now available in more than 70 countries and more than 30 million doses of PCECV have been administered worldwide. It is formulated as a single dose vial containing lyophilized vaccine (Shayam, 2006).

\section{Purified Vero Cell Rabies Vaccine (PVRV)}

PVRV contains lyophilized Wistar strain of rabies virus grown in vero cell cultures and produced in the fermentor for mass cultivation. These are developed in 1986 and are available in public and private sector upon the inactivation by $\beta$-propiolactone and purification by ultracentrifugation (Jaiiaroensup et al., 1998).

\section{Primary Hamster Kidney Cell vaccine (PHKCV)}

It is a formalin-inactivated vaccine which uses Beijing strain, propagated in primary kidney cells of Syrian hamster and is adsorbed to aluminum hydroxide. It contains human albumin and thiomersal (Dutta, 1994; WHO, 2010a). This is used in China and Russia locally.

A summary of mild and adverse effects of the above-mentioned vaccines is available in
Table 3. A list of human rabies vaccines manufactured and marketed in India is shown in Table 4.

There are two situations where the vaccine is used:

\section{Post-Exposure Prophylaxis (PEP)}

It is a procedure followed by the bite of a rabid animal. On the day of exposure, Hyper Immune Rabies Globulin (HRIG) will be given once, followed by a series of rabies vaccinations. Usually, four $1.0 \mathrm{ml}$ regimens are given from day 0 (first day of treatment) followed by days 3, 7 and 14 . The administration of PEP worldwide amounts to an estimated annual cost of US\$ 583.5 million (Fitzpatrick et al., 2012). Wound washing, passive immunization with rabies immune globulin, and a series of rabies vaccine doses are included in PEP (Lembo et al., 2010). With the availability of proper PEP, rabies in humans can be controlled and it needs to be distributed to patients for less price (Gsell et al., 2012). Rabies vaccination for infant and child immunization programs is encouraged by WHO, where canine rabies is a major public health problem (Jackson, 2013). All animal bites should be treated as category III exposure (categories explained in the following section) (NCDC, 2015).

\section{Pre-exposure prophylaxis (PrEP)}

It is used for protecting people who are at risk of infection with rabies. The schedule is 2 doses a month apart and a booster dose a year afterward. Further boosters every 2 - 3 years will be given if a risk of exposure prolongs. The high-risk group like the laboratory staff handling the virus and infected material, clinicians and persons attending to human rabies cases, veterinarians, animal handlers, wildlife wardens, travelers to rabies endemic areas will be given rabies PrEP vaccination. 


\section{Rabies immune globulin (RIG)}

Rabies immune globulin depends on the type of contact with the rabid animal.

Types of contact are: (as described by WHO, $2010 \mathrm{~b}$ - guide for rabies post-exposure prophylaxis)

Category I - touching or feeding animals, licks on the skin.

Category II - nibbling of uncovered skin, minor scratches or abrasions without bleeding, licks on broken skin.

Category III - single or multiple transdermal bites or scratches, contamination of mucous membrane with saliva from licks; exposure to bat bites or scrapes.

Rabies immune globulin (RIG) should be applied for all category III exposures. 39000 individuals come in touch with potentially rabid animals and receive rabies postexposure prophylaxis each year (Manning et al., 2008; Krebs et al., 1998). A combination of vaccine and immune globin (active and passive immunization) is seen as the acceptable PEP except for individuals who have been previously vaccinated with rabies vaccine and who present antibody titer against the infection. In this instance, the people with antibody titer will receive vaccine alone. RIGs are administered intramuscularly (into the gluteal region) in a single dose followed by a complete course of vaccine (Fahrion et al., 2016).

Types of RIGs are discussed below:

\section{Equine Rabies Immunoglobulin}

Equine Rabies ImmunoGlobulin (ERIG) obtained from horses, hyperimmunized with repeated injections of the liver rabies virus.
Currently available ERIGs are safer which contains only antigen binding $\mathrm{F}$ (ab') 2 components (Habel, 1945; Madhusudana et al., 2013), they are highly purified and are produced both in public and private sector (Wilde and Chutivongse, 1990). A skin test must be made prior to the administration of ERIG. The recommended dose is $40 \mathrm{IU}$ per kilogram body weight to the utmost of 3000 IU. Crude equine sera have been replaced by purified ERIGs (pERIGs) in order to reduce its adverse effects. Rather than preferring complete immunoglobulin, antibody parts or antigen binding $F$ (ab') 2 components are used because of their specificity and lack of reactivity (Quiambao et al., 2009). A list of ERIGs manufactured and commercialized in India is available in Table 5.

\section{Human Rabies Immunoglobulin}

Rabies immune globulin of human origin is used in combination with rabies vaccine of duck-embryo origin (DEV) (Cabasso et al., 1971; Loofbourow et al., 1971). HRIG is preferred in case of passive immunization due to the adverse reactions of the ERIG (Bahmanyar et al., 1976; ACIP, 1999). The recommended dosage of HRIG is 20 IU per $\mathrm{kg}$ body weight subject to a maximum of 1500 IU. In instances of serious exposures, HRIG is preferred (WHO, 2008) but it is constrained by cost and availability since human plasma is required for the production (Table 6).

Antibodies made from human plasma may also contain infectious agents and may also cause Creutzfeldt-Jacob Disease (CJD) (HyperRAB, 2008; Stenland et al., 2002). Viral infections or hepatitis $\mathrm{C}$ could have occurred in those who receive infusions of blood or plasma products (HyperRAB, 2008). Severe safety measures and care can be undertaken in future vaccine production to avoid all these deadly adverse effects. 


\section{Monoclonal rabies immunoglobulin}

To address the shortage of PEP, a fast acting anti-rabies human monoclonal antibody $\mathrm{RMAb}$ named as Rabishield was developed by Serum Institute of India, Pune in collaboration with MassBiologics of the University of Massachusetts Medical School. This antibody is developed because most of the patients with suspected rabies (between January 2012 and December 2014) from 11 Indian states did not receive adequate PEP (Mani et al., 2016). The rabies human monoclonal antibody RMAb is found to be safe and efficacious in clinical trials on humans over a period of nine years. This $\mathrm{RMAb}$ is supposed to be world's first fast acting anti-rabies drug (SII RMAb, 2016) in the future.

\section{A note on rabies vaccines}

Rabies vaccines should be immunogenic, cost-effective and should reduce the fatality rates in high incidence countries like India. Advanced gene transfer technology may move as a significant part in the development of novel vaccines of which some are in preclinical development stages.

Vaccine developments for rabies have seen different phases since 1885 when Pasteur invented his first live attenuated vaccine. Researches experimenting various recombinant-based vaccines have shown promising results and used for rabies control.

Keeping all vaccine efficacy studies aside, there are researches flourishing to check the potency of the rabies viral vaccine and to replace the conventional in vivo potency test method in mice. A recent survey in France by Sanofi Pasteur developed an in vitro monoclonal antibody (directed against RVG) based ELISA method to analyze the rabies viral titer (Chabaud-Riou et al., 2017).
Human death by rabies are controllable in future on budding up of different strategies, e.g. research on control measures by various means and availability of rabies vaccine. Additionally, public awareness, vaccination in domestic animals, particularly dogs, and first aid in case of animal bites decreases the disease fear. Poor experience delays the process of receiving proper PEP treatments on time and should be made available to patients who can afford to pay less (Gsell et al., 2012). Thus, both human health and public wellness, finances should benefit substantially by reduced dog rabies incidents. WHO has confirmed the statement "zero deaths by 2030 " on the $16^{\text {th }}$ World rabies day (WHO, 2016). Live but replication-deficient rabies virus vaccine developments are in progress which can shed light on single dose vaccines and possibly they would replace the current inactivated vaccines, with their related toxicity and complicated repetitive dose regimens. Safe and potent vaccines should be made comfortable for human or animal use in terms of availability, cost and the reach of treatment measures to the public. Effective reporting methods of rabies cases have to be observed for proper elimination of rabies globally.

\section{Acknowledgement}

Authors are thankful to the Director, Geniron Biolabs Pvt Ltd., Bangalore, India for providing the necessary support and motivation.

\section{References}

ACIP. Human rabies prevention--United States, 1999. Recommendations of the Advisory Committee on Immunization Practices (ACIP). MMWR. Recomm. Rep. 48:1-21

Agarwal, N., and Reddajah, V.P. 2004. Epidemiology of dog bites: a 
community-based study in India. Trop. Doct. 34:76-78

Ajjan, N., and Pilet, C. 1989. Comparative study of the safety and protective value, in pre-exposure use, of rabies vaccine cultivated on human diploid cells (HDCV) and of the new vaccine grown on Vero cells. Vaccine. 7:125-8.

Albertini, A.A., Ruigrok R.W., Blondel, D. 2011. Rabies virus transcription and replication. Adv. Virus. Res. 79:1-22

Bahmanyar, M., Fayaz. A., Nour-Salehi, S., Mohammadi, M., Koprowski, H. 1976. Successful protection of humans exposed to rabies infection. Post exposure treatment with the new human diploid cell rabies vaccine and antirabies serum. JAMA. 236:27512754

Beck, A.M. 2013. The Human-Dog Relationship: A Tale of Two Species. Dogs Zoonoses and Public Health. 2:112.

Briggs, D.J., Banzhoff, A., Nicolay, U., Sirikwin, S., Dumavibhat, B., Tongswas, S., Wasi, C. 2000. Antibody response of patients after postexposure rabies vaccination with small intradermal doses of purified chick embryo cell vaccine or purified Vero cell rabies vaccine. Bull. World. Health. Organ. 78:693-698

Cabasso, V.J., Loofbourow, J.C., Roby. R.E., Anuskiewicz, W. 1971. Rabies immune globulin of human origin: preparation and dosage determination in nonexposed volunteer subjects. Bull. World. Health. Organ. 45:303-315

CDC. 2014. Rabies-Free Countries and Political Units. Available at: https://www.cdc. gov/importation/rabies-free-countries. html

CDC. 2016. Take a Bite out of Rabies updated September 28, 2016. Available at: https://www.cdc. gov/features/rabies/

CDC. 2017. Rabies-Free Countries and Political Units. Available at: https://www.cdc. gov/importation/rabies-free-countries. html
CDC. 1998. Availability of a new rabies vaccine for human use. MMWR. 47:1219.

Chabaud-Riou., Moreno, M.N., Guinchard, F., Nicolai, M.C., Niogret-Siohan, E., Seve N., Manin, C., Guinet-Morlot, F., Riou, P. 2017. G-protein based ELISA as a potency test for rabies vaccines. Biologicals. S1045-1056, 30011-8.

Chakrabarti, P. 2010. Living versus dead: The Pasteurian paradigm and imperial vaccine research. Bull. Hist. Med. 84:387-423.

Chomel, B.B., Arzt, J.J. 2013. Dogs and Bacterial Zoonoses. Dogs Zoonoses and Public Health. 2: 67-92.

Christelle, L., Hanna, J., Stéphane, B., Mike, F., Christine, T. 2002. Rabies Virus Glycoprotein (RVG) Is a Trimeric Ligand for the N-terminal Cysteine-rich Domain of the Mammalian p75 Neurotrophin Receptor. The. J. of Biol. Chem. 277:37655-37662.

Conforti, V.A., de Avila, D.M., Cummings, N.S., Wells, K.J., Ulker, H., Reeves, J.J. 2007. The effectiveness of a CpG motifbased adjuvant (CpG ODN 2006) for LHRH immunization. Vaccine. 25: 6537-6543

Cox, J.H., Dietzschold, B., Schneider, L.G. 1977. Rabies virus glycoprotein. II. Biological and serological characterization. Infect. Immun. 16:754759

Dietzschold, B., Cox, J.H., Schneider, L.G., Wiktor, T.J., Koprowski, H. 1978. Isolation and purification of a polymeric form of the glycoprotein of rabies virus. J. Gen. Virol. 40:131-139

Dietzschold, B., Wunner, W.H., Wiktor, T.J., Lopes, A.D., Lafon, M., Smith, C.L., Koprowski, H. 1983. Characterization of an antigenic determinant of the glycoprotein that correlates with pathogenicity of rabies virus. Proc. Natl. Acad. Sci. U S A. 80:70-4.

Dr. Asma, Dr. Kiranmai, B., Dr. Vimala, T. 2016. A Cross Sectional Study on Epidemiological Profile of Patients, 
Attending Anti- Rabies Clinic in Hyderabad, Telangana, India. JMSCR. 04: 12451-12455.

Dreesen, D.W. 1997. A global review of rabies vaccine. Vaccine. 15 Suppl S2-6.

Dutta, J.K. 1994. Adverse reactions to purified chick embryo cell rabies vaccine. Vaccine. 12:1484

Dutta, J.K. 1999. Human rabies in India: epidemiological features, management and current methods of prevention. Trop. Doct. 29:196-201.

ECDC. 2016. Annual Epidemiological Report 2016 - Rabies. Available at: http://ecdc.europa.eu/en/healthtopics/ra bies/Pages/Annual-epidemiologicalreport-2016.aspx

Faber, M., Pulmanausahakul, R., Hodawadekar, S.S., Spitsin, S., McGettigan, J.P., Schnell, M.J., Dietzschold, B. 2002. Overexpression of the rabies virus glycoprotein results in enhancement of apoptosis and antiviral immune response. J.Virol. 76:3374-3381

Fahrion, S.A., Mikhailov, A., Abela-Ridder, B., Giacinti, J., Harries, J. 2016. Human rabies transmitted by dogs: current status of global data, 2015. Wkly. Epidemiol. Rec. 91:13-20.

Fielding, W.J., Gall, M., Green, D., Eller, W.S. 2012. Care of dogs and attitudes of dog owners in Port-au-Prince, the Republic of Haiti. J. Appl. Anim. Welf. Sci.15:236-253

Fitzpatrick, M.C., Hampson, K., Cleaveland, S., Meyers, L.A., Townsend, J.P., Galvani, A.P. 2012. Potential for rabies control through dog vaccination in wildlifeabundant communities of Tanzania. PLoS.Negl.Trop.Dis. 6: e1796.

Fitzpatrick, M.C., Hampson, K., Cleaveland, S., Meyers, L.A., Townsend, J.P., Galvani, A.P. 2012. Potential for rabies control through dog vaccination in wildlifeabundant communities of Tanzania. PLoS. Negl. Trop. Dis. 6: e1796.

Giesen, A., Gniel, D., Malerczyk, C. 2015. 30 Years of rabies vaccination with Rabipur: a summary of clinical data and global experience. Expert. Rev. Vaccines. 14:351-67.

Gilchrist, J., Sacks, J.J., White, D., Kresnow, M.J. 2008. Dog bites: still a problem? Inj. Prev. 14:296-301

Gluck, R., Wegmann, A., Germanier, R., Keller, H., Hess, M.W., Kraus-Ruppert, R., Wandeler, A.I. 1984. A new, highly immunogenic duck embryo rabies vaccine. Lancet. 1:844-845

Gsell, A.S., Knobel, D.L., Kazwala, R.R., Vounatsou, P., Zinsstag, J. 2012. Domestic dog demographic structure and dynamics relevant to rabies control planning in urban areas in Africa: the case of Iringa, Tanzania. BMC. Vet. Res. 8:236

Habel, K. 1945. Seropprophylaxis in experimental rabies. Public. Health. Rep 60:545-60.

Hafkin, B., Hattwick, M.A., Smith, J.S., Alls, M.E., Yager, P.A., Corey, L., Hoke, C.H., Baer, G.M. 1978. A comparison of a WI-38 vaccine and duck embryo vaccine for preexposure rabies prophylaxis. Am. J. Epidemiol. 107:439-443

Hampson, K., Coudeville, L., Lembo, T., Sambo, M., Kieffer, A., Attlan, M., Barrat, J., Blanton, J.D., Briggs, D.J., et al., 2015. Correction: Estimating the global burden of endemic canine rabies. PLoS. Negl. Trop. Dis. 9: e0003786

Hemachudha, T., Ugolini, G., Wacharapluesadee, S., Sungkarat, W., Shuangshoti, S., Laothamatas, J. 2013. Human rabies: neuropathogenesis, diagnosis, and management. Lancet. Neurol. 12:498-513

Hiby, E. 2013. Dog Population Management. Dogs Zoonoses and Public Health. 2:177-204.

HSI, India. 2016. Available at: http://www.hsi. org/world/india/news/releases/2016/04/

hisar-dog-population-managementprogram-first-year-040616.html

HYPERRAB, S/D. 2008. Human rabies virus immune globulin injection, Talecris Biotherapeutics, Inc. Available at: 
https://dailymed.nlm.nih.gov/dailymed/ archives/fdaDrugInfo.cfm? archiveid=51 366

Jackson, A.C. 2007. Human disease. Rabies. pp: 309-40. 2nd Edn., Elsevier Academic Press, London.

Jackson, A.C. 2010. Rabies pathogenesis update. Rev. Pan-Amaz. Saude. 1:167172.

Jackson, A.C. 2013. Current and future approaches to the therapy of human rabies. Antiviral. Res. 99:61-67

Jahnavi, R.,Vinay, M., Manuja, L.M., Anil Kumar, K.2014. Clinico Epidemiological profile of wild animal bite victims attending anti rabies clinic at government tertiary care centre in Mandya. J. of Evolution of Med and Dent Sci. 3:14257

Jaiiaroensup, W., Lang, J., Thipkong, P., Wimalaratne, O., Samranwataya, P., Saikasem, A., Chareonwai, S., Yenmuang, W., Prakongsri, S., Sitprija, V., Wilde, H. 1998. Safety and efficacy of purified Vero cell rabies vaccine given intramuscularly and intradermally. Vaccine. 16:1559-1562

Jemima, E.A., Manoharan, S., Kumanan, K. 2014. Development and evaluation of a recombinant-glycoprotein-based latex agglutination test for rabies virus antibody assessment. Arch. Virol. 159:1987-1993

Keller, H., Gluck, R., Wegmann, A., Wandeler, A.I. 1984. Immunogenicity of a new, highly purified, highly concentrated duck-embryo rabies vaccine. Schweiz. Med. Wochenschr. 114:648-653

Kinge, K.V., Supe, A.C. 2016. Epidemiology of animal bite cases reported to anti-rabies vaccination OPD at a tertiary-care hospital, Nagpur. Int. J. Med. Sci. Public. Health. 5:1579-1582.

Knobel, D.L., Cleaveland, S., Coleman, P.G., Fevre, E.M., Meltzer, M.I., Miranda, M.E., Shaw, A., Zinsstag, J., Meslin, F.X. 2005. Re-evaluating the burden of rabies in Africa and Asia Review. Bull. World. Health. Organ. 83:360-8.
Kole, A.K., Roy, R., Kole, D.C. 2014. Human rabies in India: a problem needing more attention. Bull. World. Health. Organ. 92:230

Krebs, J.W., Long-Marin, S.C., Childs, J.E. 1998. Causes, costs, and estimates of rabies postexposure prophylaxis treatments in the United States. J. Public. Health. Manag. Pract. 4:56-62

Kucera, P., Dolivo, M., Coulon, P., Flamand, A. 1985. Pathways of the early propagation of virulent and avirulent rabies strains from the eye to the brain. J. Virol. 55:158-162

Kulkarni, S.K. 2016. Trend of Animal Bite Victims Reported to Anti Rabies Vaccination Clinic At A Tertiary Care Hospital Nanded Maharashtra. Journal of Dental and Medical Sciences. 15: 3639.

Kutzler, M., Wood, A. 2006. Non-surgical methods of contraception and sterilization. Theriogenology. 66: 514525.

Lembo, T., Hampson, K., Kaare, M.T., Ernest, E., Knobel, D., Kazwala, R.R., Haydon, D.T., Cleaveland, S. 2010. The feasibility of canine rabies elimination in Africa: dispelling doubts with data. PLoS. Negl. Trop. Dis. 4:e626

Lentz, T.L., Burrage, T.G., Smith, A.L., Crick, J., Tignor, G.H. 1982. Is the acetylcholine receptor a rabies virus receptor. Science. 215:182-4.

Loofbourow, J.C., Cabasso, V.J., Roby, R.E., Anuskiewicz, W. 1971. Rabies immune globulin (human). Clinical trials and dose determination. JAMA. 217:18251831

Lycke E., Tsiang, H. 1987. Rabies virus infection of cultured rat sensory neurons. J. Virol. 61:2733-2741

Madhusudana, S.N., Ashwin, B.Y., Sudarshan, S. 2013. Feasibility of reducing rabies immunoglobulin dosage for passive immunization against rabies: results of In vitro and In vivo studies. Hum.Vaccin.Immunother. 9:1914-1917 
Mani, R.S., Anand, A.M., Madhusudana, S.N. 2016. Human rabies in India: an audit from a rabies diagnostic laboratory. Trop. Med. Int. Health. 21:556-563

Manning, S.E., Rupprecht, C.E., Fishbein, D., Hanlon, C.A., Lumlertdacha, B., Guerra, M., Meltzer, M.I., Dhankhar, P., Vaidya, S.A., Jenkins, S.R., Sun, B., Hull, H.F. 2008.

Human rabies prevention--United States, 2008. Recommendations of the Advisory Committee on Immunization Practices. MMWR. Recomm. Rep. 57:1-28

McGettigan, J.P. 2010. Experimental rabies vaccines for humans. Expert. Rev. Vaccines. 9:1177-1186.

Morgan, E.R. 2013. Dogs and Nematode Zoonoses. Dogs Zoonoses and Public Health. 2: 153-161.

Morgan, M., Palmer, J. 2007. Dog bites. BMJ. 334:413-417

Munson, L. 2006. Contraception in fields. Theriogenology. 66: 126-34.

NCDC, 2015. National Centre for Disease Control, National Guidelines on Rabies Prophylaxis. Available at: http://www. ncdc.gov.in/writereaddata/mainlinkfile/ File557.pdf

Nogueira, Y.L. 1998. Adverse effect versus quality control of the FuenzalidaPalacios antirabies vaccine. Rev. Inst. Med. Trop. Sao Paulo. 40:295-299

OIE, 2010. Stray Dog Population Control. Chapter. 7.7. Available from: http://web.oie.int/eng/normes/mcode/en _chapitre_1.7.7.pdf

Plotkin, S., Koprowski, H., Rupprecht, C.E 2008. In Plotkin, Orenstein and Offit (Eds). Vaccines. pp 687-717.

Plotkin, S.A. 1977. New rabies vaccine halts disease-without severe reactions. Mod. Med. 45:45-8.

Purswell, B.J., Kolster, K.A. 2006. Immunocontraception in companion animals. Theriogenology. 66:510-3.

Quiambao, B.P, Dy-Tioco, H.Z., Dizon, R.M., Crisostomo, M.E., Teuwen, D.E. 2009. Rabies post-exposure prophylaxis with purified equine rabies immunoglobulin: one-year follow-up of patients with laboratory-confirmed category III rabies exposure in the Philippines. Vaccine. 27:7162-7166

Rabinowitz, P.M., Gordon, Z., Odofin, L. 2007. Pet-related infections. Am. Fam. Physician. 76:1314-1322

Shayam, C., Duggal, A.K., Ulka Kamble., Agarwal, A.K. 2006. Post-exposure Prophylaxis for Rabies. JIACM. 7:3946.

SII RMAb. 2016. Available at: http://www.seruminstitute.com/content/ prod_pipe2.htm

Spiegel, I.B. 2000. A Pilot Study to Evaluate an Elementary School-based Dog Bite Prevention program. Anthrozoos. 13: 164-173.

Stenland, C.J., Lee, D.C., Brown, P., Petteway, S.R., Rubenstein, R. 2002. Partitioning of human and sheep forms of the pathogenic prion protein during the purification of therapeutic proteins from human plasma. Transfusion. 42:14971500

Thoulouze, M.I., Lafage, M., Schachner, M., Hartmann, U., Cremer, H., Lafon, M. 1998. The neural cell adhesion molecule is a receptor for rabies virus. Virol. J. 72:7181-90.

Tintinalli, Judith, E. 2010. Emergency Medicine: A Comprehensive Study Guide [Emergency Medicine (Tintinalli)]. McGraw-Hill., pp: Chapter 152.

Tsiang, H., Ceccaldi, P.E., Lycke, E. 1991. Rabies virus infection and transport in human sensory dorsal root ganglia neurons. J. Gen. Virol. 72:1191-1194

Tuffereau, C., Leblois, H., Benejean, J., Coulon, P., Lafay, F. 1989. Arginine or lysine in position 333 of ERA and CVS glycoprotein is necessary for rabies virulence in adult mice. Virology. 172:206-12.

Van der Zee, A., Noordegraaf, C.V., Van den Bosch, H., Gielen, J., Bergmans, H., Hoekstra, W., et al., 1995. P-fimbriae of Escherichia coli as carriers for 
gonadotropin releasing hormone: development of a recombinant contraceptive vaccine. Vaccine. 13: 753-8.

Venkatesan, M., Dongre, A.R., Kalaiselvan, G. 2014. An epidemiological study of animal bites and envenomings in a rural district of Tamilnadu India. Online. J. Health. Allied. Sci. 13: 4.

Vigilato, M.A., Clavijo, A., Knobl, T., Silva, H.M., Cosivi, O., Schneider, M.C., Leanes, L.F., Belotto, A.J., Espinal, M.A. 2013. Progress towards eliminating canine rabies: policies and perspectives from Latin America and the Caribbean. Philos. Trans. R. Soc. Lond. B. Biol. Sci. 368:20120143

WHO. 2008. Rabies vaccines. WER 82:425-36. Available from: http://www.who.int/ wer/2007/wer8249_50.pdf?ua=1.

WHO. 2010a. Grading of scientific evidence. Table III: Safety of cell-culture- based rabies vaccines. Available from: http://www.who.int/immunization/rabie s_grad_safety.pdf

WHO. 2010b. WHO GUIDE for Rabies Pre and Post Rabies Pre and Post-exposure Prophylaxis in Humans - Department of Neglected Tropical Diseases Neglected Zoonotic Diseases team (revised 15 June 2010). Available from: http://www.who.int/rabies/PEP_prophyl axis_guidelines_June10.pdf

WHO. 2012. Information sheet observed rate of vaccine reactions rabies vaccine.
Available from: http://www.who.int/ vaccinesafety/initiative/tools/RabiesVac cineratesinformationsheet.pdf

WHO. 2013a. WHO Expert Consultation on Rabies. 2: 1-138. Available from: http://apps.who.int/iris/bitstream/10665/ 85346/1/9789240690943_eng.pdf

WHO. 2013b. Animal bites, Fact sheet. Available from: http://www.who.int/ mediacentre/factsheets/fs373/en/

WHO.2016. Rabies, Fact sheet. Available from: http://www.who.int/mediacentre/factshe ets/fs099/en/

Wiktor, T.H. 1980. Virus vaccines and therapeutic approaches. In Bishop HD ed. Rhabdomyoviruses. 99-112.

Wiktor, T.J., Gyorgy, E., Schlumberger, D., Sokol, F., Koprowski, H. 1973. Antigenic properties of rabies virus components. J. Immunol. 110:269-276

Wilde, H. Chutivongse, S. 1990. Equine rabies immune globulin: a product with an undeserved poor reputation. Am. J.Trop.Med.Hyg. 42:175-178

WSPA. 2007. World Society for the Protection of Animals (WSPA): Companion Animals Unit, non-surgical methods for controlling the reproduction of dogs and cats. Internal document: guidance for WSPA staff and member societies. Available from: www.wspainternational.org.

\section{How to cite this article:}

Sunil Abraham, Jayaishrei Ravindran, Nishawlini Abishaw, Nathaniel Philip Sandam, Prashanth Thimmareddy and Goutham Govindaraju. 2017. Review on Rabies and Vaccines. Int.J.Curr.Microbiol.App.Sci. 6(12): 2064-2085. doi: https://doi.org/10.20546/ijcmas.2017.612.237 